\title{
AN ISLAMIC VIEW OF INTERNATIONAL COMMERCIAL LAW (COMPARATIVE STUDY)*
}

\author{
Mostafa MIRMOHAMMADI, assistant professor of international law, director of Center for comparative law studies, Mofid \\ University \\ P. O. Box: 37185-3611, Mofid sq., Qom, Iran \\ E-mail: CCLS@mofidu.ac.ir
}

This article addresses comparative study of some ethical and legal rule in Islamic Jurisprudence (Figh). The first aim of this study is a review of Islamic teaching in the realm of commercial law and the second - is seeking and introducing similar concepts in the other legal systems. Therefore, the article divided in two sections. In the first section the author discusses about those principles and rules govern on international trades and next section will intrude some commercial ethical codes in Islamic teaching.

Keywords: Islamic jurisprudence, UNCTAD, commercial law, Muslim jurists, ethical rule.

DOI: $10.12737 / 21255$

\section{Introduction}

The importance of international trade is that human beings are interdependent and any restriction or unjust limitation on the way of providing basic commodities is a kind of loss to the people. Accordingly all nations and civilizations have had their specials traditions and custom regards trades of foods, clothes and weapons with others. Muslim jurists also considered in Islamic texts importance of internal and international trade to provide basic goods for Islamic societies. They recognized and introduced ethical and legal principles in this regards. "Mutual interest", "Mutual consent" and "No harm No damage" are well known principles in this matter".

One of the most important part of Islamic jurisprudence is book of trade, (Kitab Al Tejarah) in which various Islamic schools discusses in detail about codes and manner of commerce in these sections. Nowadays one of the most important books in Islamic seminaries is, Ketab Al Matajer, which means book of commerce which are being studied and thought through argumentive and deductive manner. As an example the Book of Commerces written by Shaikh Mortaza Al Ansari - who is one of the Shia eminent jurists in the past century - is the most detailed deductive book in the subject of contracts and commerces based on Jafari jurisprudential school of thought. It divided in to three parts: employments and business, buying and selling and cotracts conditions and options (Khiarat) and circumstances when and how a contract can be terminated. Almost all of jurisprudential books have specified some part of their subjects to the commerce discussion. It shows that ethical and legal aspects of trade have always been the center of discussion by Muslim Jurists.

There are many different between trades in the time of early Islam and in the past centuries with in our time. Today some undeniable realities are prevailing in international economic and trade relations:

* Перевод статьи на русский язык см. на с. $112-119$ настоящего выпуска Журнала.

${ }^{1}$ Cf.: Ahmad Abū al-Wafā: Kitāb al-ilām bi-qawāid al-qānūn al-dawlī wa-al-alāqāt al-dawlīyah fī sharīat al-Islām, (Arabic) Dar Al-Nahdzah Al-Arabiah, Cairo, 2007, Vol. 11. P. 262.
Firstly; in the files of exports and imports, States on the one hand truing to increase imports by encouragement to export, discounting the tax and Dumping Policy. And the other hand they trying to decrease imports by competition policy for local goods, increasing customs duty and implementation of economic austerity policies.

Second; while incomes of developing and less developed countries are depended on their exporting raw materials the costs of these materials are always unstable in global market, but in the contrary the cost of industrial goods are determined by multinational corporations located in developed countries and always increasing more.

Third; the economic differences and gaps between countries are undeniable which divided countries to richer countries the North and poorer countries the South. As we know, UNCTAD, the Group of 77 and new international economic Order (NIEO) were some of attempts to decrease this distance and bridging the gap between these two kinds of countries ${ }^{2}$.

In spite of all changes that happened in our time but the trade is never closed and all legal systems have many principles and rules in this regards. Islam as one of the current great legal system has its specific views and approaches about trade in Islamic societies an in international level.

This paper does not consider all aspects of the commerce in Islamic teaching and to find answers for all of them but main purpose of this article is to introduce some ethical and legal codes and norms in Islamic teaching which is recognized at the light of jurisprudential manner in the case commerce and trade. These codes and norms are combinations of ethic and law which shows that presence of humanitarian dimensions in the context of trade.

\section{Islamic Rules and principles on International} trade

According to all Muslim jurists opinion trade between Muslims and non-Muslims is permitted. It shows that Islamic law is essentially protects peaceful relations. Prophet Mohammad (PBUH) when he was young traveled to Syria for the sake of trade. He was getting many

\footnotetext{
${ }^{2}$ Cf.: Ahmad Abū al-Wafā: Op. cit. Vol. 11. Pp. 235-239.
} 
offers, from different people, to take trade caravans to different parts of the Arabian Peninsula. One of the richer merchants was Khadijah, who was very successful in trade. She was not able to do trade herself so she hired men to do her bidding on her behalf. Khadija became interested in hiring Muhammad for a trade Journey and asked him to take a trade caravan to Syria. This trade journey was an opportunity that Prophet Mohammad and khadije were married. Based on some Qurnice verses and tradition of Prophet, some authors are trying to introduce examples of trade that Islamic legal system has encouraged commerce in the international level ${ }^{3}$.

Islamic jurists and lawyers relying on two principal sources, Qurqn and Tradition of prophet of Islam, and commercial conduct of Muslim merchants, have accepted and introduced some commercial usages and principles like as "mutual interest" "reciprocity" and "do no harm no damage" and so on ${ }^{4}$.

Nevertheless, some important rules and principles has recognized in the realm of international commerce in Islamic teaching are as follows:

1.1. Consent principle. This principle rooted in Quranic verse which specifies to believers to regard mutual consent and trade freedom of on trade and do not behave unjustly in the transaction of goods and commodities.

"O you have believed, do not consume one another's wealth unjustly but only [In lawful] business by mutual consent". (Nisa verse 29.)

Trade on the basis of consent is a general rule in Islamic law and because its Quranice base has been studied and discussed in detail in Islamic Figh. Commercial limitations are made mentioned clearly in Islam. There are two main limitations; selling and buying wine and pig between Muslims and selling those kinds of weapons may be used against Muslims in the future. With considering these two conditions there is not obstacle in front of trade freedom and Principle of consent but also the principle of "Treaties are observed" or Pacta sunt servanda will govern and respected in this regards. Therefore the contract is subject to limitations which agreed on. This concept is similar to first article of UNUDROIT that stipulates:

"The parties are free to enter into a contract and to determine its content"s.

1.2. Inviolability and protection of merchants. At the Islamic political and legal texts one can find status of merchants in the time of war and peace. In the seventh century, Imam Ali wrote a recommendation letter to his appointed governor to Egypt at the time of his dispatch to this territory. In this very important ethical and governmental text, Imam Ali mentioned administrative and political division of the state and their authorities.

\footnotetext{
${ }^{3}$ Ahmad Abū al-Wafā: Op. cit. Pp. 242-248.

${ }^{4}$ Ibid. Pp. $250-251$.

${ }^{5}$ UNIDROIT Principles of International Commercial Contracts, 2010.
}

Among the seven groups of peoples in the society he mentioned specifically about role of merchants and traders in order of any society. Since this instrument is a governmental charter its content is too important for religious reading from commercial affairs. In this content, merchants are introduced as people who prepare basic goods and Commodities by their capital and traveling to different places. So they accept the risk and difficulties for transferring and changing goods from remote areas to near places. Merchants are described as origin of peace. It means that their presence may cause peace and security because trade between two nations will strengthen among them. In the other word trade relation is means of friendly relation and presence of merchants are causes of peace ${ }^{6}$.

Some words of Imam Ali about merchants are that:

I want to advise you about your businessmen and industrialists. Treat them well, and order your officers to follow the same policy... They all are the sources of wealth to the country. They provide goods for the consumers. Most of these traders carry and convey these goods from across deserts, seas and over open lands and mountains, their consignments are brought from distant lands, often from places which are not easy to approach and where usually people do not care or do not dare to go. These businessmen are usually peace-loving people, not given to mischievous disturbances and seditious fomentation. You must look after their interest and protect them whether they are trading in your cities or towns or whether they are traveling over the countries carrying goods from place to place. One more thing about these traders and industrialists, While treating them most sympathetically, you must keep an eye over there activities as well.

You know they are usually stingy misers, intensely self-centered and selfish, suffering from the obsession of grasping and accumulating wealth.

They often hoard their goods to get more profit out of them by creating scarcity and by indulging in blackmarketing. Such a condition is extremely injurious to the public on one hand and disgraceful to the ruler on the other.

You must put a stop to all such practices because the Holy Prophet (s) has explicitly prohibited such practices. Remember that trade should go on between the buyers and sellers according to correct measures and weights and on such reasonable terms that neither the consumers nor the suppliers should have to face losses. But even with all the sympathetic treatments accorded to them and with all the facilities provided to them, if the traders and industrialists carry on hoarding and black-marketing, then you must punish them according to the intensity of their crime?

This is because some jurists added merchants and peasants to protected Persons in the time of war. Although

\footnotetext{
${ }^{6}$ Nahj Al Balaghe saying and letter of Imam Ali(Arabic) Mahamad abodoh Interpretation, Dar Alzakher, 1412 Al-Hijiyah, Vol. 3. Pp. 99-100.

${ }^{7}$ Nahj al-Balaghah: Peak of Eloquence. $3^{\text {rd }}$ ed. Trans, Sayed 'Ali Reza, Elmhurst, Tahrike Tarsile, 1984, Letter 53. Pp. 256-257.
} 
this is a minority opinion, it proves that the distinction between combatant and non-combatant enemies was clear in the minds of those jurists ${ }^{8}$. On the other hand, this outcome shows that most traders who are advocate peace atmosphere because at the time of peace they can reach to their profit. Also some jurists have protected merchants beside of envoys and ambassadors. They stipulated that these two groups are protected by Islam and no one can do aggression to them ${ }^{9}$.

Allameh Helli in his Comparative book says that; when a non Muslim merchant entered into Islamic territories for the purpose of trade while he thinks that is in safe he will have right to inviolability and must escort him to where he can be secure ${ }^{10}$.

Obviously, trader to be entitled to protection, it is necessary to stay away from non-commercial activities and comply with the provisions of Islamic state. It is clear that every businessman must comply with the regulations of that territory in which the commercial activities carried on.

1.3. Customs duties. Like nowadays, customs duties are levied on imports and exports Muslim Jurists also recognized a kind of customs for international trade called Tithe (Oshre). This tax was levied for merchandise which brought to Islamic lands from overseas. It is known that this kind of tax was initiated by Omar second caliph of prophet. He was received this custom from merchants in order to securing trade routes. Also, in a letter was sent to Caliph by one of his governors asking about amount of non-Muslim traders taxes, Caliph replied: To the extent that they receive from yours, you have the same behavior. Indeed in this letter the principle of "Reciprocity" were accepted in dealing with foreign merchants ${ }^{11}$. This principle is acceptable now.

1.4. Limitations on Trades. Like many legal systems, in Islamic law trade are faced with some limitations and conditions. As a general rule, trade with non Muslim is permitted where there is no usury in it and wine and pig trading are forbidden. Also arms trade and transaction is forbidden with non-Muslims if the sold weapons strengthen the power of the non Muslims against Muslims. The reason of this sensitivity and judgment is clearly explained by Islamic jurists. I mean it may be used against Muslims. This finding shows that, in the view of these jurists arm sanction was one the first steps to prevent conflicts and preserve peace. Anyway, in our times, Islamic states are buying weapons from developed countries and biggest arms buyers from the West, are some of the Islamic richest states ${ }^{12}$.

\footnotetext{
${ }^{8}$ Mahmassani Sobhi: The principles of international law in the light of Islamic doctrine, Recueil des cours, Vol. 117 (1966-I). P. 102 .

${ }^{9}$ Ahmad Abū al-Wafā. Op. cit. Pp. 270-272.

${ }^{10}$ Ibn Mottahar (Allameh Helli) Tazkeratol Foghaha(Arabic) Al Albayt, Vol. 9. P. 105.

${ }^{11}$ Ahmad Abū al-Wafā: Op. cit. Pp. 278-279, 282.

${ }^{12}$ Based on Stockholm International Peace Research Institute (SIPRI) report in March 2015, the five biggest exporters in 2010 - 14
}

On the other words, Muslim Jurists have forbidden arms trade with non Muslim because of their concerns about risk of war and using them against Muslims. But transaction of weapon if not lead to the strengthening of the enemy this is not prohibited ${ }^{13}$.

There is no doubt that great legal systems have become familiar with each others systems through commercial transaction. Islam also went to many parts of the world through businessmen and commercial relation ${ }^{14}$.

Concerning interaction of international commercial relation between Islamic states and European countries, Judge Christopher Weeramantry, who was judge at International Court of justice for nine years from 1991, said that:

"There had been contact between Christian and Islamic civilization both in war and peace for many centuries dating back to Crusades. The crusaders encountering such monarch as Saladin saw the observance by them principles of international law, including truces between warring parties during which the rival leaders even met at convivial social gatherings. Peaceful contact throw trade likewise exposed the west to Islamic concepts of international trade, and influenced international commercial law"15.

In addition, about commercial law in Islam, Mahmasani in his course at Hague Academy of International law said that:

"Commercial intercourse had a great impact on the expansion of Islamic religion and Arab civilization. Through this intercourse, goods as well as ideas were exported from the East to West. Islamic commercial law also left its imprint on Western trade. Bills of exchange and assignment of debts (Hawaleh), known in Islamic law and practice as early as the eight century A.D, were introduced into Europe four centuries later via Italy during the Crusades and via Spain when it was still an Arab Province. The French word "aval" which means the endorsement of a bill of exchange by a guarantor is derived from the Arabic word "hawalaw"(assignment). Another French word, "avaries" is also derived from the Arabic word "iwar" this is another illustration of the valuable contribution made by Islam to international commerce and international of peace"16.

At the end of this section, it is proper to remember here an example of commercial contract signed between Muslims and European territories. Some privileges were granted to the Florentine merchants through commercial

were the USA, Russia, China, Germany and France and the five biggest importers in 2010-14 were India, Saudi Arabia, China, the UAE and Pakistan. See: Pieter D. Wezeman and Siemon T. Wezeman, SIPRI Fact Sheet march 2015. Pp. 1, 4.

${ }^{13}$ Ahmad Abū al-Wafā: Op. cit. Pp. 288-294.

${ }^{14}$ Mahmassani Sobhi: Op. cit. P. 71.

${ }^{15}$ Christopher Weeramantry: Islamic Jurisprudence: An International Perspective, Macmillan Press, London, 1988. P. 149.

${ }^{16}$ Mahmassani. Op. cit. Pp. 71-72. 
contract between Florence and Egypt signed by Sultan Qaitbay, in 1488, are fallows:

1. Every Florentine merchant paid their customary administrative dues no one shall trouble them after that with extortion or impose innovations upon them. This protect includes their ships merchandise...

2. For every transaction between Florentine merchants and our merchants, it is necessary to be present some witnesses.

3. When there is within the Florentine nation dispute or quarrels or one of them has a right against another of his nation no one of viceroys or magistrates or merchants shall adjudicate between them except the consul of their nation according to their custom or to their satisfaction in that.

4. In the case of dispute between Muslim merchant and Florentine merchant, if both are willing to deal with before the Sultan, necessary coordinate and facilitate should be taken in this regard.

5. In case of death of a Christian businessman, Merchandise of deceased businessman will be sold by monitoring of their consul.

6. In case of piracy by Muslim ships, against Christian ships, those ships will be confiscated and perpetrators will send to Sultan for punishment ${ }^{17}$.

This commercial contract shows that protection of merchants and his merchandise, commercial disputes settlement based on mutual consent, merchant usages ${ }^{18}$ or say "lex mercatoria" 19 and universal jurisdiction for piracy were known between Muslims and European in the fifteen century.

Marcel A. Boisard described this commercial contract by these words:

"...after three years of negotiation, this treaty appears rather as a decree from the Sultan to his administration in Egypt and the Syrian Levant than as a bilateral and reciprocal international instrument binding the two parties. Apart from the mere safeguard of the merchants and a guarantee of their rights, the treaty enters into many details, such as customs taxes (14 percent), administrative fees, the establishment of a consul among the merchants in their own funduq, ways of settling

\footnotetext{
${ }^{17}$ Ahmad Abū al-Wafā: Op. cit. P. 264. For more detail about this contract see: John Wansbrough, «A Mamluk Commercial Treaty Concluded with the Republic of Florence, 894/1489» in S. M. Stem, ed., Documents from Islamic Chanceries, Oriental Studies III (Oxford: B. Cassirer, 1965). Pp. 39-79.

${ }^{18}$ Article 44 of Alamajallh (Ottoman Code) stipulated that: "A matter recognised by merchants is regarded as being a contractual obligation between them" See: Al-Majallah Al Ahkam Al Adliyya (The Ottoman Courts Manual (Hanafi)) Part II. Maxims of Islamic Jurisprudence.

${ }^{19}$ Fatima Akaddaf: Application of the United Nations Convention on Contracts for the International Sale of Goods (CISG) to Arab Islamic Countries: Is the CISG Compatible with Islamic Law Principles? Pace International Law Review. No. 13 (2001). Pp. 29-30.
}

credits, and so on. It even includes the possibility of arbitration by the Sultan between Florentines and any other nation or race on Mamluk territory or seas. Even if it introduces some juridical principles which follow European practices, this commercial treaty adheres closely in content to Muslim law and traditions, referring for in- stance to the Shariah (art. 8 and (6) and to the huquq shar'iyya (art. 18 and 20)"20.

\section{Ethical Rule of commerce in Islamic teachings}

Developing of ethical and behavioral rules for some profession is necessary in which commerce is one of them. Nowadays besides of medical ethic, ethical Code and Conduct for attorneys and lawyer, technical and professional code and so on, The Code of conduct or ethics for businessmen also is considered more and more important ${ }^{21}$.

Fortunately, ethical rules have a worth place in Islamic jurisprudence and teaching. For implementation of these rules some religious and legal commitments have been predicted. This section tries to introduce some ethical and legal rule on trade in Islamic teaching as comparative manner. Relation between ethic and law in Islam is very closely. These two well-known statements indicate this firm relation: "Justice is the base of Islamic rules" and "I have just chosen to complete moral values" Prophet Mohammad (PBUH) said.

Relationship between ethic and law in commercial rules and principles can be divided in two spheres; Recommended act (Mostahabat) or reprehensible act or undesirable or discouraged (Makrohat) ${ }^{22}$ and Obligatory (Vajibat) or forbidden (Haram).

2.1. Recommended or reprehensible trade in Islam. Narrative and jurisprudential texts under title of "Code of commerce" (Adab Al-Tejarah) examined some of conducts taking place in the commercial operation which can be placed in the category of recommendations or in reprehensible (undesirable) act ${ }^{23}$ :

\footnotetext{
${ }^{20}$ Marcel A. Boisard: On the Probable Influence of Islam on Western Public and International Law. Courtesy: International Journal of Middle East Studies 11 (July 1980). P. 433.

${ }^{21}$ As an example see: Basic Guidelines for Codes of Business Conduct, was developed by the U. S. Department of Commerce in cooperation with the Russian Chamber of Commerce, Available at: http://ita.doc.gov/goodgovernance/adobe/bem_appendices/ appendix_b.pdf.

22 The word of "Makruh" Means: Not approved, Undesirable from the point of view of religion, although not punishable. A term used in Islam for an act the unlawfulness of which is not absolutely certain, but which is considered improper and unbecoming. See: Deeb Al-Khudrawi: Dictionary of Islamic Terms English-Arabic \& Arabic English, Al Yamamah, Damascus Beirut \& Darussalam. P. 499.

${ }^{23}$ Cf.: Al-Ameli, Sheikh Hor:Vasayelo Al-Shyie,(The Means of Shi'ites) Mo-asesat Al- Albyt, Qom, Vol. 17. Pp. 381-447; Al-Ameli, Zain Al-din bin Ali (1978), Al-Rouda Al-Bah'yah fi Sharh Al-Lom'ah, Dar Ehya Altorath Alarabi, Beirut, 1983,
} 
1. Bing aware of commercial issues to be avoids usury and greed $^{24}$.

2. Respect to equality and non discrimination: Political and social position of party of the contract or transaction should not affect the rate and amount of transactions ${ }^{25}$.

3. It is undesirable to enter the market (Bazar) early and leaving late from it: in fact, being away from greed and avarice, giving others the opportunity to earn, also stay away from theft are among the purpose of this ethical rule ${ }^{26}$.

4. It is undesirable to Use swearing in buying or selling: because swearing may increases or decrease the desire of the buyer or seller in purchasing, therefore this ethical code aims to prevent using God and religious beliefs as ways and means for more incoming ${ }^{27}$.

5. It is undesirable to enter transaction with those who have suspected properties ${ }^{28}$ : Indeed, Anti-Money Laundering lies behind of this teaching.

6 . Interfere in trading of another who is close to agreement is undesirable: Foe example, if one offers more money or less to the seller or the buyer to dissuade from this agreement, it would be a kind of jobbery at the expense of another. That is why some jurists are of the opinion that this kind of inferences is prohibited ${ }^{29}$. However, if it goes to happen like tenders or auctions which acceptance of more or less suggestion is on the hand of other party, there is no interference in this situation. Non interference to other transaction which is closed to agreement, it teaches a kind of ethical monitoring on the competitive conduct in market and commerce.

7. Going to meet the caravan of traders for anticipatory transaction is undesirable ${ }^{30}$ : anticipation to buy or sell with caravan traders which are still in the path of entrance in to city is undesirable and some jurists said; it is forbidden. The reason for this is that those merchants who are coming in to the city are not aware of real price in it, so they sell or buy goods cheaper or more expensive than real price. This behavior is a kind of monopoly, therefore some

Vol. 3. Pp. 285-301; Nadjafi, Mohammad Hassan: Javaher Al-kalam fi Al-sharhSharaye' Al-Islam, 1986, $8^{\text {th }}$ ed., Dar al-kotob Alislamiah, Tehran,Vol. 22. P. 449 onward: Mir Mohammad Sadeghi Hossein: refeltion of rules of ethics on the Iranian and Islamic law of commerce (Persian), Comparative law Review, Mofid University,Vol. 8. No. 1. 2012. Pp. 53-56.

${ }^{24}$ Al-Ameli, Sheikh Hor: Op. cit. Vol. 17. Pp. 381-382.

${ }^{25}$ Ibid, P. 398; Al-Ameli, Zain Al-din bin Ali: Op. cit. Vol. 3. P. 286.

${ }^{26}$ Al-Ameli, Sheikh Hor: Op. cit. P. 468; Al-Ameli, Zain Al-din bin Ali: Op. cit. P. 293; Mir Mohammad Sadeghi Hossein: Op. cit. P. 53.

${ }^{27}$ Al-Ameli, Sheikh Hor: Op. cit. Pp. 419-421; Al-Ameli, Zain Al-din bin Ali: Op. cit. P. 290; Mir Mohammad Sadeghi: Op. cit. P. 53.

${ }^{28}$ Al-Ameli, Zain Al-din bin Ali: Op. cit. P. 294.

${ }^{29}$ Ibid. Pp. 295-296.

${ }^{30}$ Ibid. P. 297. jurists prohibited to buy from someone who went to meet commercial caravan out of the city and bought from them.

8. To praise oneself goods and taunt about other commodities: this conduct in Islamic teaching is disliked and undesirable ${ }^{31}$. Supporting the production of highquality goods by client's choice and fight against fraud are inter alia among the purpose of this tenet. This guideline also prohibits improper method of advertising and competition.

9. It is recommended to accept suggestion of contract annulment from someone who does not like to continue. On the other words announcement of "withdraw after selling is possible» indicated "customer orientation" which nowadays sometimes is considered in ethical business charters $^{32}$.

10. It is recommended to prayer and God's remembrance in the time of commerce ${ }^{33}$ : this teaching is caused to keep religious conscience aware and regarding recommendations and ethical criteria, also respect to human values in the time of commerce.

The above mentioned are some of ethical codes and conducts one can be found in the Islamic jurisprudence collections (Figh) in commercial manners of conducts. Although these items are not obligatory but we can consider them as guidelines which might regulate human conducts in terms of commerce towards more humane societies.

2.2. Obligatory and forbidden trade in Islam. Some tenets in Islamic Jurisprudence have titled: "Obligation" or Prohibition. This kind of division is very determiner in the realm of commerce and other aspects of Islamic law as well. Some of them are below:

1. Fulfillment of obligation (Pacta sunt servanda). Fulfillment of obligation and keeping on commitments is one of the basic principle that accepted by civilized nation. This principle In Islam, originated from Quranic verse that says: "O you who believe, fulfill your obligation" (Maedeh:1).

This principle also includes commercial commitments which are not contrary to peremptory rules. Therefore if the merchandise is not prohibited goods, like wine and pig, and exporting of goods to enemies do not help them against Muslims, so there is no obstacle in front of international trade ${ }^{34}$.

In addition to Quran, the prophet's tradition emphasized on fulfillment of obligation, his saying "The believers are with their conditions" is well known in all Islamic sources. Muslim jurists are of this opinion that one of the meanings of "condition" in this saying is contract and obligation. Based on this saying, Muslims

\footnotetext{
${ }^{31}$ Al-Ameli, Zain Al-din bin Ali: Op. cit. Pp. 291-293.

${ }^{32}$ Mir Mohammad Sadeghi Hossein: Op. cit. P. 55.

${ }^{33}$ Al Muhaqqiq al-Hilli: Sharai al-Islam fi masail al-Halal wa-al-Haram (English) translated by: Hasan. M. Najafi, Ansariyan Publication, Iran, 2003. Vol. 2. P. 24.

${ }^{34}$ Ahmad Abū al-Wafā: Op. cit. P. 263.
} 
should be faithful to their promises unless the violation is essential or in the jurisprudential words: the obligatory norms (Vajib) changed into forbidden (Haram) and vice versa. Other jurisprudential word in Arabic and Islamic text in this regard is: "Al-aghd shariat Al-Mota aghedin $)^{35}$ it means that "contracts must be respected "or "a contract is a law between the parties". However this similar concept is reflected in the civil laws of many countries like article 1134 of French civil code stipulated that: "Agreements lawfully entered into take the place of the law for those who have made them" and" "they may be revoked only by mutual consent or for causes authorized by law'. Article 147 of Egypt civil code, 148 Syrian civil code and article 10 of Iranian civil code has almost similar words ${ }^{36}$.

2. Good faith (Hosne Al-Niyat). Good faith principle in the fulfillment of contract is reflected in many internal and international instruments among them commercial instrument which indicated influence of ethic upon laws or closing relate between law and ethic. Good faith and fulfillment of commitments are two important principles which considered in performing of treaties. Good faith also is considered as an ethical rule in process of negotiations and interpretation of treaties. Nevertheless, what is stipulated in article 26 of law of treaty convention 1969 that: "Every treaty in force is binding upon the parties to it and must be performed by them in good faith" can be considered another general principles recognized by civilized nations among them Islamic law emphasized on it, as well. In addition, what is stipulated in article 7.1 of UNIDROIT Principles of International Commercial Contracts stated that: "Each party must act in accordance with good faith and fair dealing in international trade" is also confirmed in Islamic teaching.

3. Prohibition of undue influence. One of the rules that indicated the effect of ethical criteria on contracts and transaction is undue influence. According to this rule was accepted in western legal systems, among them English law, it would prevented one person taking advantage of a position of power over another person. By applying this rule, commercial contracts between individuals, such as lawyers and his clients, patients and doctors, religious leaders and followers of the religion, and others in such a manner that one party can imposed his/her influence against another party, are invalid .

In the Islamic law and teaching, in the light of "Do no harm" rule, it is not recognized those contracts which one party signed it with the abuses of his influence. This similar notion is seen in the law of some Islamic and Arabic countries for instance article 159 of Kuwait civil

35 انبيدقاعتملا :عيرش دقعل See also: Fatima Akaddaf: Op. cit. P. 44

${ }^{36}$ Mir Mohammad Sadeghi Hossein: Op. cit. Pp. 56-57. Article 10 of Iran's civil code stipulated that, Private contracts shall be binding on those who have signed them, providing they are not contrary to the explicit Provisions of a law. code, Article 189 of UAE civil code and article 1240 civil code of Iran.

4. Prohibition of consuming people's property unjustly. One another very important title in Islamic law in the fields of commerce and employment is prevention from unjustly wealth consuming". This principle originated from Quran that says:

"O you have believed, do not consume one another's wealth unjustly but only [In lawful] business by mutual consent." (Nisa verse 29.)

According to this verse Quran, forbids using the prohibited methods to take people's money and properties. In the quranic word, eating each other's property is forbidden by illicitly ways. But trade is excluded because trade is a good mediator between industry and consumers and it promotes for commodities and sells them.

This general title include all kind of unlawful manners for wealth obtaining like bribery, gambling, usury, breach of trust and those contract are against public order and ethic, would be invalid. In addition according to this principle those commerce causes oppression against to others is forbidden. This Quranic verse did as a guideline and basic principle in Islamic commercial jurisprudence and Led to the deepest research on the fields of trade.

It may be said that the notion of "Unjust enrichment" in the west legal system is closest conception to prohibition of "Unjustly wealth consuming" in the east and Islamic legal system.

In order to applying this rule, $49^{\text {th }}$ principle of Iran's constitution stipulated that:

"The government has the responsibility of confiscating all wealth accumulated through usury, usurpation, bribery, embezzlement, theft, gambling, misuse of endowments, misuse of government contracts and transactions, the sale of uncultivated lands and other resources subject to public ownership, the operation of centers of corruption, and other illicit means and sources, and restoring it to its legitimate owner; and if no such owner can be identified, it must be entrusted to the public treasury. This rule must be executed by the government with due care, after investigation and furnishing necessary evidence in accordance with the law of Islam".

\section{Conclusion}

The aim of this article was to introduce some principles and ethical aspects of commerce in Islamic jurisprudence, including internal and international level, and to present similar concepts in the other legal systems. Muslim jurists under titles of obligatory or forbidden trades also under recommended or discouraged conducts in commerce were seeking ethical and legal rules in Islamic teaching. What is known nowadays as ethical code of conduct in commerce or charter of ethical business was not hidden from view of Muslim jurist and lawyer. Ethical rules can be considered as a background for legal protection. Moving morel code into legal norms is required state cooperation, Intergovernmental and non governmental organization 
(NGOo,s) and commercial institutions as well. The role of these organizations in incorporating ethical rule into areas of commercial corporation activities is undeniable. In fact moral commercial rule likes soft-law can gradually entered into hard-law arena. Now respect of ethical rule in commerce became more important than before. In order to protecting human rights criteria, powerful economic state and developed countries in their relation with developing countries have to maintain ethical standards of commerce have humanitarian motives in its nature. These ethical principles are not only Islamic but are human principles which have root in great religions teachings. Respecting for human rights and values are sensory in performance of any unilateral or international sanction.

If we seek to define commercial principles only in its legal principles, we moved them toward more interest oriented and more gap between the people. But if these principles accompanied with ethical reading then important steps have taken toward more humane international trade and implementation of general principle which accepted by civilized nations. And this is the mission of comparative law.

\section{REFERENCES}

Ahmad Abū al-Wafā: Kitāb al-ilām bi-qawāid al-qānūn al-dawlī wa-al-alāqāt al-dawlīyah fī sharīat al-Islām, (Arabic) Dar Al-Nahdzah Al-Arabiah, Cairo, 2007, Vol. 11.

Nahj al-Balaghah: Peak of Eloquence. $3^{\text {rd }}$ ed. Trans, Sayed 'Ali Reza, Elmhurst, Tahrike Tarsile, 1984, Letter 53.

Mahmassani Sobhi: The principles of international law in the light of Islamic doctrine, Recueil des cours, Vol. 117 (1966-I).

Ibn Mottahar (Allameh Helli) Tazkeratol Foghaha(Arabic) Al Albayt, Vol. 9.

Christopher Weeramantry: Islamic Jurisprudence: An International Perspective, Macmillan Press, London, 1988.

John Wansbrough, «A Mamluk Commercial Treaty Concluded with the Republic of Florence, 894/1489» in S. M. Stem, ed., Documents from Islamic Chanceries, Oriental Studies III (Oxford: B. Cassirer, 1965).

Al-Majallah Al Ahkam Al Adliyya (The Ottoman Courts Manual (Hanafi)) Part II. Maxims of Islamic Jurisprudence.

Fatima Akaddaf: Application of the United Nations Convention on Contracts for the International Sale of Goods (CISG) to Arab Islamic Countries: Is the CISG Compatible with Islamic Law Principles? Pace International Law Review. No. 13 (2001).

Marcel A. Boisard: On the Probable Influence of Islam on Western Public and International Law. Courtesy: International Journal of Middle East Studies 11 (July 1980).

Deeb Al-Khudrawi: Dictionary of Islamic Terms English-Arabic \& Arabic English, Al Yamamah, Damascus Beirut \& Darussalam.

Al-Ameli, Sheikh Hor:Vasayelo Al-Shyie,(The Means of Shi'ites) Mo-asesat Al- Albyt, Qom, Vol. 17.

Nadjafi, Mohammad Hassan: Javaher Al-kalam fi Al-sharhSharaye' Al-Islam, 1986, 8 ${ }^{\text {th }}$ ed., Dar al-kotob Alislamiah, Tehran, Vol. 22.

Mir Mohammad Sadeghi Hossein: refeltion of rules of ethics on the Iranian and Islamic law of commerce (Persian), Comparative law

Review, Mofid University,Vol. 8. No. 1. 2012.

Al Muhaqqiq al-Hilli: Sharai al-Islam fi masail al-Halal wa-al-Haram (English) translated by: Hasan. M. Najafi, Ansariyan Publication, Iran, 2003. Vol. 2. 